\title{
Measurement of haematological indices of chronic rheumatic disease with two newer generation automated systems, the $\mathrm{H} 1$ and H6000 (Technicon)
}

\author{
L Turner-Stokes, D Jones, K G Patterson, A Todd-Pokropek, D A Isenberg, A H Goldstone
}

\section{Bloomsbury}

Rheumatology Unit,

Department of

Rheumatology Research,

University College

and the Middlesex

School of Medicine,

London

L Turner-Stokes

D Jones

D A Isenberg

Bloomsbury

Rheumatology Unit,

Department of

Haematology,

University College

and the Middlesex

School of Medicine, London

K G Patterson

A $\mathbf{H}$ Goldstone

Faculty of Clinical

Sciences,

University College,

London

A Todd-Pokropek

Correspondence to:

Dr Lynne Turner-Stokes,

Department of

Rheumatology,

Wheumatology,

St Mary's Wing,

Highgate Hill,

London N19 SNF.

Accepted for publication

30 October 1990
Abstract

Two automated counters, the HI (Technicon) and the H6000 (Technicon), which count 10000 cells per sample, were compared and used to examine the clinical relevance of the additional haematological information now provided to the rheumatologist in three groups of patients-38 with rheumatoid arthritis (RA), 41 with ankylosing spondylitis (AS), and 35 with systemic lupus erythematosus (SLE).

The two machines agreed in their estimations of the main indices (haemoglobin, red blood cell count, and white blood cell count), but estimations of platelet count and volume were significantly lower on the H6000 machine, as were mean cell haemoglobin and monocyte count, whereas packed cell volume and red cell distribution width were higher. As expected, both machines identified pancytopenia among the group with SLE, while low haemoglobin and high platelet count were found particularly among patients with $R A$ and AS respectively. Additional information available from these counters showed marked variability in red cell size in SLE, and also of haemoglobin content, which is only measured on the newer H1 machine. Flags for microcythaemia, anisochromasia, and white cell noise (usually due to nucleated red cells) were all more common in SLE. Interpretation of results was complicated by the inevitable difference in age and sex distribution among the disease groups, and identification of active disease was also limited by the effect of drugs.

In conclusion, the increasingly widespread use of automated counters as part of the routine haematological service may provide the rheumatologist with useful information, but, as always, care should be taken in the interpretation of indices in patients receiving non-steroidal or second line agents, and also in extrapolating results from one machine to another when they are updated or when patients are monitored at more than one centre.

Rheumatic diseases are accompanied by a variety of haematological abnormalities. For example, patients with rheumatoid arthritis (RA) may show hypochromic anaemia ${ }^{1}$ and thrombocytosis, ${ }^{2}$ especially in active disease; whereas patients with systemic lupus erythematosus
(SLE) have been reported to show lymphopenia, ${ }^{3}$ basophilopenia, ${ }^{4}$ and neutrophil left shift. ${ }^{5}$

Automated machines which count 10000 cells per sample (compared with the 100 cells counted by traditional manual methods) have become a powerful tool for assessing abnormalities among the cell populations in peripheral blood. Previous studies have used these techniques to document abnormalities in haematological indices associated with RA (as compared with a disease control group of patients with ankylosing spondylitis (AS)) ${ }^{6}$ and with SLE. ${ }^{7}$

As technology advances, however, newer machines have replaced the Hemalog D (Technicon) counter used in these studies, and these second generation machines perform to different specifications. Moreover, they are no longer just a research tool but are now standard equipment in most major haematology laboratories. A reappraisal of the haematological indices of rheumatic disease, as assessed by current automated counters, is warranted.

In this study two automated counters, the H6000 (Technicon) and Hl (Technicon), were compared. A wide range of haematological indices were assessed in three groups of patients with rheumatic diseases-38 with RA, 41 with AS, and 35 with SLE-to establish whether these technical advances give consistent results, contribute to distinguishing the diseases, and whether they are affected by the level of disease activity and concomitant drug treatment.

\section{Patients and methods}

PATIENTS

Patients attending clinics in the Bloomsbury rheumatology unit during a six week study period were selected if $(a)$ they were aged between 18 and 75, (b) they fulfilled the diagnostic criteria for one of the disease categories, and (c) venesection was carried out before 1400 hours, to allow the sample to be processed the same day. Each of the 38 patients with RA fulfilled the American Rheumatism Association revised criteria for the classification of RA, ${ }^{8}$ and the 35 patients with SLE fulfilled the 1982 revised American Rheumatism Association criteria for the classification of SLE. ${ }^{9}$ Forty one patients with AS, each of whom met the New York criteria for diagnosis, ${ }^{10}$ were also studied. 
In patients with RA and AS disease activity was classified according to published criteria. ${ }^{6}$ Disease activity among patients with SLE was graded according to a previously published index,${ }^{11}$ which has recently been validated with an activity index generated by a more detailed computer based programme. ${ }^{12}$ Table 1 shows the distribution of age, sex, and disease activity among the different patient groups.

\section{BLOOD COUNTERS}

Two $5 \mathrm{ml}$ venous blood samples were anticoagulated in EDTA tubes (Vacutainer) and analysed by $\mathrm{Hl}$ and $\mathrm{H} 6000$ (Technicon) machines the same day. Both instruments measure the following indices: total white cell count, red blood cell count, haemoglobin, mean

Table 1 Distribution of age, sex, and disease activity among the different patient groups. Results are given as number (\%) of patients

\begin{tabular}{|c|c|c|c|}
\hline & $\begin{array}{l}A S^{*} \\
(n=41)\end{array}$ & $\begin{array}{l}S L E^{*} \\
(n=35)\end{array}$ & $\begin{array}{l}R A^{*} \\
(n=38)\end{array}$ \\
\hline $\begin{array}{l}\text { Disease activity: } \\
\text { Inactive } \\
\text { Moderately active } \\
\text { Active/severely active }\end{array}$ & $\begin{array}{r}31(76) \\
3(7) \\
7(17)\end{array}$ & $\begin{array}{c}7(20) \\
17(49) \dagger \\
11(31) \ddagger\end{array}$ & $\begin{array}{r}12(32) \\
21(55) \\
5(13)\end{array}$ \\
\hline $\begin{array}{l}\text { Sex: } \\
\quad \text { Male } \\
\text { Female }\end{array}$ & $\begin{array}{l}29(71) \\
12(29)\end{array}$ & $\begin{array}{r}3(9) \\
32(91)\end{array}$ & $\begin{array}{l}11(29) \\
27(71)\end{array}$ \\
\hline $\begin{array}{l}\text { Age groups: } \\
<25 \\
25-45 \\
46-60 \\
>60\end{array}$ & $\begin{array}{r}2(5) \\
23(56) \\
11(27) \\
5(12)\end{array}$ & $\begin{array}{r}4(11) \\
20(57) \\
7(20) \\
4(11)\end{array}$ & $\begin{array}{r}1(3) \\
6(16) \\
13(34) \\
18(47)\end{array}$ \\
\hline
\end{tabular}

*AS=ankylosing spondylitis; SLE=systemic lupus erythematosus; RA=rheumatoid arthritis †Mildly active.

$\ddagger$ Moderately and severely active.

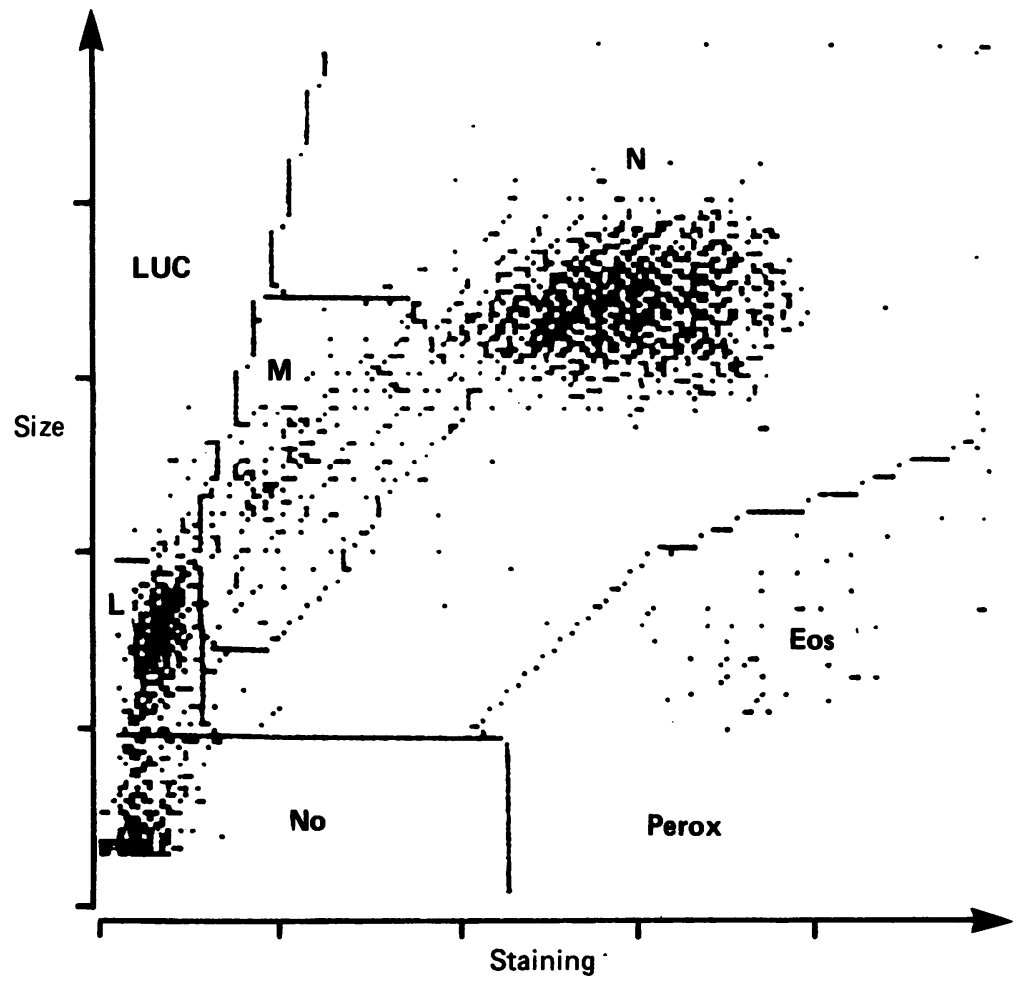

The $H 1$ peroxidase display for normal blood. The vertical axis represents cell size, the horizontal axis staining intensity for peroxidase. Each cell is represented by a dot on the graph. Mobile thresholds divided the display into cell types as follows: eosinophils (Eos) with strong peroxidase staining; neutrophils (N) with moderate staining; monocytes $(M)$ with weak staining; and lymphocytes $(L)$ with none. The bottom left hand box $(N o)$ is noise of low staining and low size, which is excluded from the count. LUC=large unstained cells. cell volume, mean cell haemoglobin, mean cell haemoglobin concentration, red cell size distribution width, platelets, mean platelet volume, the volume percentage of platelets in whole blood, platelet size distribution width, large unstained cells, neutrophils, lymphocytes, monocytes, eosinophils, and basophils.

In both instruments haemoglobin is measured by standard cyanmethaemoglobin methods, and cell number and size by optical methods. The differential white count is performed by staining the cells for the enzyme peroxidase. About 10000 white cells are assessed for staining intensity and size, the results being displayed graphically (figure). The white cells form discrete populations on the graph, depending on their size and staining. Lymphocytes are of medium size and low staining intensity, monocytes are large and have slight peroxidase staining. Neutrophils have moderate, and eosinophils, heavy staining. Mobile computer controlled thresholds hunt the cell populations and count them

There are, however, certain methodological differences between the two instruments. On the H6000 basophils are specifically stained with alcian blue and counted in a separate channel, whereas on the $\mathrm{Hl}$ machine sodium dodecyl sulphate is used to strip the cytoplasm from all cells, except basophils, which are then counted on the basis of size. Reactive lymphocytes and primitive cells negative for peroxidase are detected in both instruments as 'large unstained cells' on the peroxidase channel. In addition, the $\mathrm{H} 1$ detects these on the basophil channel, and generates a 'blast' flag. The $\mathrm{H} 6000$ has automatically adjusting thresholds for the neutrophil population, but the $\mathrm{H} 1$ has additional mobile thresholds for counting the other cell populations.

For the red cell population the mean cell volume on the $\mathrm{H} 6000$ is measured by summation of pulse heights, but on the $\mathrm{Hl}$ a technique of computer generated 'red cell mapping' using laser light scatter from sphered red cells is used. The $\mathrm{Hl}$ has the ability to generate graphical representations of red cell size distribution and haemoglobin content, and also measures variation in the haemoglobin content of red blood cells (haemoglobin distribution width). Finally, the $\mathrm{Hl}$ is also physically smaller than the $\mathrm{H6000}$ and does not require a supply of deionised water or a waste pipe attachment.

\section{CALIBRATION OF COUNTERS}

Both instruments were calibrated using fresh EDTA blood samples against the Coulter S-Plus IV counter, which used 4C Plus as the primary calibrant. This method of secondary calibration was used to ensure consistency of results from all instruments within the laboratory. Mean cell volume was separately calibrated by assessment of the running mean, which remains constant from day to day for this patient group. The differential count was calibrated by processing fresh normal samples and adjusting the thresholds of the instruments, where necessary, to enclose normal leucocyte populations. 
Table 2 Comparison of $\mathrm{Hl}$ and $\mathrm{H} 6000$ measurements of blood cell indices (Student's t test). Results are given as mean $(S E)$

\begin{tabular}{|c|c|c|c|}
\hline Index & $H I$ & $H 6000$ & $\begin{array}{l}\text { Significance } \\
\text { ( } p \text { value })\end{array}$ \\
\hline $\begin{array}{l}\text { Total white cell count }\left(\times 10^{9} /\right) \\
\text { Red cell count }\left(\times 10^{12} /\right) \\
\text { Haemogloblin }(g / 1) \\
\text { Packed cell volume } \\
\text { Mean cell haemoglobin }(\mathrm{pg}) \\
\text { Red cell size distribution width }(\%) \\
\text { Platelets }\left(\times 10^{9} /\right) \\
\text { Mean platelet volume (fl) } \\
\text { Platelet size distribution width }(\%) \\
\text { Platelets in whole blood } \\
\text { Neutrophils }\left(\times 10^{9} /\right) \\
\text { Lymphocytes }\left(\times 10^{9} / 1\right) \\
\text { Monocytes }\left(\times 10^{9} /\right) \\
\text { Eosinophils }\left(\times 10^{9} /\right) \\
\text { Basophils }\left(\times 10^{9} /\right) \\
\text { Large unstained cells }\left(\times 10^{9} / 1\right)\end{array}$ & $\begin{array}{cl}6.7 & (0.2) \\
4.4 & (0.5) \\
127 & (2) \\
0.368 & (0.004) \\
34.1 & (0.2) \\
13.9 & (0.2) \\
346 & (10) \\
7.9 & (0 \cdot 1) \\
50.7 & (0.3) \\
0.271 & (0.008) \\
4.5 & (0.2) \\
1.6 & (0.1) \\
0.42 & (0.15) \\
0.14 & (0.01) \\
0.05 & (0.00) \\
0.06 & (0.00)\end{array}$ & $\begin{array}{ll}6.6 & (0.2) \\
4.3 & (0.6) \\
123 & (2) \\
0.380 & (0.006) \\
31.9 & (0.4) \\
18.7 & (2) \\
250 & (8) \\
6.3 & (0.1) \\
50.8 & (0.6) \\
0.195(0.005) \\
4.5 \quad(0.2) \\
1.6 \quad(0.1) \\
0.31 \quad(0.01) \\
0.15(0.01) \\
0.04(0.00) \\
0.05(0.00)\end{array}$ & $\begin{array}{l}\text { NS } \\
\text { NS } \\
\text { NS } \\
<0.02 \\
<0.02 \\
<0.02 \\
<0.001 \\
<0.001 \\
\text { NS } \\
<0.001 \\
\text { NS } \\
\text { NS } \\
<0.001 \\
<0.03 \\
\text { NS } \\
<0.02\end{array}$ \\
\hline
\end{tabular}

\section{STATISTICS}

Statistical analysis was performed using the statistical package for the social sciences (SPSS) at the University of London computing centre. Direct comparison between the two machines was made using paired Student $t$ tests. Unpaired non-parametric statistics were used to test differences between the diagnostic groups, and variation between clinical subgroups of different disease activity, treatment, etc, within each diagnostic category. The Mann-Whitney $U$ test was used for comparison of two groups of data, and the Kruskal-Wallis one way analysis of variance was used where three or more groups were compared.

\section{Results}

COMPARISON OF THE HI AND H6000 MACHINES

The two machines were generally found to agree in their estimations of the main indices - that is, haemoglobin, red blood cell count and total white cell count. They differed significantly, however, in their estimations of platelet count, mean platelet volume, and the percentage of platelets in whole blood, which were lower on the $\mathrm{H6000}$, as were mean cell haemoglobin and monocyte counts. Packed cell volume and red cell size distribution width were significantly higher as measured by the $\mathrm{H} 6000$ (table 2). There was no significant difference in their estimations of neutrophil, lymphocyte, and basophil counts. Small numerical differences in the eosinophil and large unstained cell counts were not regarded as biologically significant.

\section{HAEMATOLOGICAL INDICES IN THE DIFFERENT \\ DISEASE GROUPS}

Table 3 shows the number of estimations above and below the normal range in each disease group. Statistical differences in the range of values between disease groups were assessed by Kruskal-Wallis one way analysis of variance. Both machines showed the haemoglobin, red blood cell count, and packed cell volume to be lowest in SLE, then in RA, and highest in AS $(p<0.005)$. Conversely, the red cell size distribution width was higher in SLE and RA $(p<0.002)$, and so was the haemoglobin distribution width $(\mathrm{p}<0.04)$, which is only available

Table 3 The number of observations of haematological indices which fall outside the normal range in each disease group*

\begin{tabular}{|c|c|c|c|c|c|c|c|}
\hline \multirow[t]{2}{*}{ Index ${ }^{*} \ddagger$} & \multirow[t]{2}{*}{ Normal range } & \multicolumn{3}{|c|}{ Values below normal } & \multicolumn{3}{|c|}{ Values above normal } \\
\hline & & $\underset{(n=41)}{A S}$ & $\begin{array}{l}S L E \\
(n=35)\end{array}$ & $\begin{array}{l}R A \\
(n=38)\end{array}$ & $\underset{(n=4 l)}{A S}$ & $\begin{array}{l}S L E \\
(n=35)\end{array}$ & $\begin{array}{l}R A \\
(n=38)\end{array}$ \\
\hline 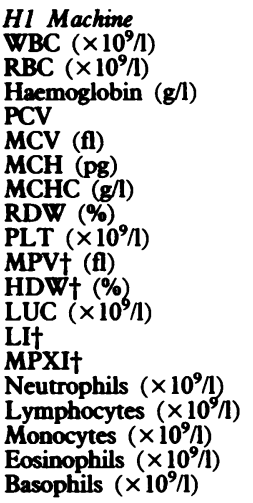 & $\begin{array}{l}4 \cdot 8-10 \cdot 8 \\
4 \cdot 2-6 \cdot 1 \\
120-180 \\
0 \cdot 37-0 \cdot 52 \\
80-99 \\
27-31 \\
330-370 \\
11 \cdot 5-14 \cdot 5 \\
130-400 \\
7 \cdot 2-11 \cdot 1 \\
2 \cdot 2-3 \cdot 2 \\
0-0 \cdot 4 \\
1 \cdot 9-3 \\
-10-+10 \\
1 \cdot 1-8 \cdot 0 \\
0 \cdot 9-5 \cdot 2 \\
0 \cdot 16-1 \\
0-0 \cdot 8 \\
0-0 \cdot 2\end{array}$ & $\begin{array}{r}4 \\
8 \\
5 \\
1 \\
3 \\
6 \\
13 \\
1 \\
0 \\
10 \\
3 \\
0 \\
0 \\
3 \\
0 \\
1 \\
1 \\
0 \\
0\end{array}$ & $\begin{array}{r}16 \\
19 \\
15 \\
27 \\
8 \\
5 \\
7 \\
0 \\
0 \\
5 \\
2 \\
0 \\
0 \\
2 \\
0 \\
8 \\
3 \\
0 \\
0\end{array}$ & $\begin{array}{r}1 \\
11 \\
14 \\
17 \\
10 \\
9 \\
10 \\
0 \\
0 \\
5 \\
4 \\
0 \\
0 \\
1 \\
0 \\
2 \\
0 \\
0 \\
0\end{array}$ & $\begin{array}{r}0 \\
0 \\
0 \\
0 \\
2 \\
10 \\
8 \\
3 \\
10 \\
0 \\
1 \\
0 \\
0 \\
3 \\
0 \\
0 \\
0 \\
0 \\
0\end{array}$ & $\begin{array}{r}0 \\
0 \\
0 \\
0 \\
0 \\
6 \\
2 \\
12 \\
6 \\
0 \\
6 \\
0 \\
0 \\
0 \\
2 \\
0 \\
0 \\
0 \\
0\end{array}$ & $\begin{array}{l}3 \\
0 \\
0 \\
0 \\
1 \\
6 \\
0 \\
9 \\
0 \\
0 \\
2 \\
0 \\
0 \\
4 \\
2 \\
0 \\
0 \\
0 \\
0\end{array}$ \\
\hline $\begin{array}{l}\text { H6000 Machine } \\
\text { WBC }\left(\times 10^{9} / 1\right) \\
\text { RBC }\left(\times 10^{9} / 1\right) \\
\text { Haemoglobin }(\mathrm{g} / \mathrm{l}) \\
\text { PCV } \\
\text { MCV (fl) } \\
\text { MCH (pg) } \\
\text { MCHC (g/1) } \\
\text { RDW (\%) } \\
\left.\text { PLT ( } \times 10^{9} / 1\right) \\
\text { MPV (f) } \\
\text { Neutrophils }\left(\times 10^{9} / 1\right) \\
\text { Lymphocytes }\left(\times 10^{9} / 1\right) \\
\text { Monocytes }\left(\times 10^{9} / 1\right) \\
\text { Eosinophils }\left(\times 10^{9} /\right) \\
\text { Basophils }\left(\times 10^{9} / 1\right) \\
\text { LUC }\left(\times 10^{9} / 1\right)\end{array}$ & $\begin{array}{l}3 \cdot 8-11 \cdot 0 \\
3 \cdot 7-6 \cdot 2 \\
115-172 \\
0 \cdot 35-0 \cdot 51 \\
80-98 \\
27-33 \\
310-355 \\
11 \cdot 5-16 \\
150-400 \\
7 \cdot 2-11 \cdot 1 \\
2 \cdot 0-7 \cdot 2 \\
1 \cdot 1-3 \cdot 8 \\
0 \cdot 1-0.95 \\
<0 \cdot 48 \\
<0 \cdot 1 \\
<4\end{array}$ & $\begin{array}{r}0 \\
2 \\
9 \\
5 \\
2 \\
13 \\
18 \\
0 \\
0 \\
38 \\
0 \\
1 \\
0 \\
0 \\
0 \\
0\end{array}$ & $\begin{array}{r}8 \\
4 \\
12 \\
12 \\
4 \\
5 \\
8 \\
0 \\
7 \\
23 \\
4 \\
10 \\
4 \\
0 \\
0 \\
0\end{array}$ & $\begin{array}{r}1 \\
4 \\
12 \\
11 \\
5 \\
10 \\
9 \\
0 \\
2 \\
34 \\
0 \\
8 \\
2 \\
0 \\
0 \\
0\end{array}$ & $\begin{array}{r}\mathbf{0} \\
\mathbf{0} \\
\mathbf{0} \\
\mathbf{0} \\
1 \\
\mathbf{3} \\
2 \\
27 \\
\mathbf{0} \\
\mathbf{0} \\
\mathbf{0} \\
\mathbf{0} \\
\mathbf{0} \\
\mathbf{1} \\
\mathbf{0} \\
\mathbf{0}\end{array}$ & $\begin{array}{r}1 \\
1 \\
0 \\
1 \\
1 \\
2 \\
1 \\
31 \\
0 \\
0 \\
2 \\
0 \\
0 \\
0 \\
1 \\
0\end{array}$ & $\begin{array}{r}2 \\
1 \\
2 \\
2 \\
1 \\
2 \\
2 \\
36 \\
3 \\
0 \\
3 \\
0 \\
0 \\
1 \\
0 \\
0\end{array}$ \\
\hline
\end{tabular}

*Normal range not yet established for platelet crit and platelet size distribution width.

Performance characteristics not yet established-for research only.

FWBC=total white cell count; $R B C=$ red cell count; $P C V=$ packed cell volume; $M C V=$ mean cell volume; $M C H=$ mean cell haemoglobin; $M C H C=$ mean cell haemoglobin concentration; $R D W=$ red cell size distribution width; $P L T=$ platelets; $M P V=$ mean platelet volume; HDW = haemoglobin distribution width; LUC=large unstained cells; LI=lobularity index (index of lobularity of neutrophils); MPXI=mean peroxidase index (index of staining intensity of neutrophils). 
on the H1. Platelets and the percentage of platelets in whole blood were lowest in SLE and highest in AS $(p<0.03)$. There was significant panleucocytopenia in SLE, compared with RA and AS $(p<0.001)$, in both machines, and this included large unstained cells on the $\mathrm{H6000}$ $(\mathrm{p}<0.001)$. In addition, the $\mathrm{Hl}$ machine has a number of flags for certain red and white cell abnormalities. Flags for microcythaemia, anisochromasia, and white cell noise (usually due to nucleated red cells) were all more common in SLE $(p<0.04)$.

\section{CORRELATIONS WITH DISEASE ACTIVITY AND DRUG TREATMENT}

As expected, increasing disease activity in patients with AS was associated with a fall in haemoglobin $(p<0.02)$ and a rise in platelets $(p<0.03)$ and, in particular, the percentage of platelets in whole blood $(p<0.003)$, but this association was not significant in RA. Active SLE, however, was associated with lower basophil counts than inactive SLE $(p<0.03)$ on the H6000 machine, but not on the H1.

One of the problems in assessing the effect of treatment and disease activity in blood indices is that they may influence each other. For instance, it may only be the patients with more active disease who are taking non-steroidal antiinflammatory drugs (NSAIDs) or immunosuppressive drugs, but on the other hand, patients receiving such drug treatment may have their disease well controlled and display few signs of activity when studied. The following results are reported with these reservations in mind.

Twenty three of 41 (56\%) patients with AS and 26 of $38(68 \%)$ patients with RA were receiving NSAIDs. In RA, haemoglobin and packed cell volume were estimated by both machines to be significantly lower in those receiving NSAIDs (Mann-Whitney, $\mathrm{p}<0.02$ ). Likewise, platelets and the percentage of platelets in whole blood were higher in patients with AS receiving NSAIDs on the $\mathrm{Hl}(\mathrm{p}<0.02)$, but not the $\mathrm{H} 6000$ machine. Only five of the patients with SLE were receiving NSAIDs, so no significant differences were found in this group.

Similarly, none of the patients with AS were receiving steroids or immunosuppressive drug treatment. Twenty one of $35(60 \%)$ patients with SLE and 9/38 (24\%) of those with RA were receiving steroids or immunosuppressive drugs (azathioprine or cyclophosphamide), or both. In patients with SLE steroid or immumosuppressive drug treatment, or both, was associated with higher red cell size distribution width and haemoglobin distribution width, and with eosinopenia and lymphopenia on the $\mathrm{Hl}$ $(p<0.02)$, and with basopenia and erythropenia on the $\mathrm{H} 6000(p<0.04)$. In patients with RA such treatment was associated with neutrophilia and lymphopenia, and higher haemoglobin distribution width, according to the $\mathrm{Hl}(\mathrm{p}<0.02)$.

\section{Discussion}

Since automated counters have become generally available much additional information and more variables are added to the conventional blood count. The purpose of this study was to assess whether this additional data is of clinical relevance to the rheumatologist in a study of three common rheumatic diseases. It is important to recognise, however, that this is a continuing process. Newer instruments are constantly coming into use. It is therefore pertinent to ask whether these different machines provide consistent information in their interpretation of the same peripheral blood sample. This study has focused on two counters in recent use, the $\mathrm{Hl}$ (Technicon) and the H6000 (Technicon), but even in the time taken to prepare this paper the latter has already been superseded.

Certain important differences between the $\mathrm{H} 1$ and the $\mathrm{H} 6000$ machines have been highlighted. These in turn reflect differences in design and in the techniques which the two instruments use to measure a given population of cells, as described in the 'Methods' section. Earlier reports, using manual counts, suggested that basopenia is associated with active disease in SLE. ${ }^{13}$ This finding was not confirmed in the earlier study which used the Hemalog $D,{ }^{7}$ but our study reaffirms the association, at least on the $\mathbf{H 6 0 0 0}$. The instruments may therefore be identifying different populations of cells, depending on their different clinical characteristics.

Particularly surprising was the marked discrepancy between mean platelet volume estimations on the two machines, which were consistently higher on the $\mathrm{Hl}$ machine, often by as much as $\mathbf{3 0} \%$. Although it should be noted that the mean platelet volume is one of the most labile of the blood count indices, this difference may be artefactual. The mean platelet volume is to some extent time dependent, as platelets tend to shrink after venepuncture. Although every effort was made to process the samples simultaneously (and certainly on the same day), the H6000 was sited in another hospital, and the time which elapsed during transportation might therefore account for the lower mean platelet volume values recorded by the $\mathrm{H} 6000$ as compared with the $\mathrm{H} 1$ machine. Differences in calibration might also have played a part, and this highlights the potential dangers of comparing serial counts made by different machinesfor example, where a patient is followed up in a specialist department but has interim blood counts at a local centre.

It was hoped that some of the additional blood indices available from automated counters might be helpful in distinguishing the different rheumatic disease states, but this did not prove to be the case. As expected, SLE was characterised by pancytopenia; RA by low haemoglobin, red blood cell count, packed cell volume, and mean cell volume; and AS by low haemoglobin and high platelet count. Further investigation was complicated by differences in age and sex distribution between the different disease categories. In addition to the expected haematological features in SLE, there were indications of marked variability in red cell size (red cell size distribution width) and haemoglobin content (haemoglobin distribution width) on the 
H1. It is our personal experience that variability in cell shape and size in both red and white cell populations is often apparent on inspection of a peripheral blood film from patients with SLE, but to our knowledge this has not yet previously been measured.

The role of these machines in the identification of active disease is also limited by concomitant drug treatment, which may alter the recirculation patterns of cell populations in the peripheral blood. For example, the lower haemoglobin and higher platelet count seen in the patients with active AS may reflect disease activity, but might just as well reflect gastrointestinal blood loss, as these patients were also receiving more NSAIDs. The association between leucopenia and increased haemoglobin distribution width with active SLE could likewise reflect the steroids and immunosuppressive drugs that most of the patients with active disease were taking.

In conclusion, therefore, the introduction of automated counters as part of the routine haematology service may provide the rheumatologist with additional useful information. Care should be taken, however, in interpretation of haematological indices in patients who are receiving NSAIDs, steroids, or immunosuppressive drugs. Because different methodology is used in different models of the machines, care should also be taken in extrapolating results from one machine to the next, when they are updated or when patient care is shared between two centres using different machines. This problem has the potential to increase under NHS reform if, as a result of competing service contracts, patients attend more than one hospital for different aspects of their care.

1 Bodel P T, Hollingsworth J W. Comparative morphology, respiration and phagocytic function of leucocytes from blood and joint fluid in rheumatoid arthritis. $\mathcal{f}$ Clin Invest 1966; 45: 580-9.

2 Hutchinson R M, Davis P, Jayson M I V. Thrombocytosis in rheumatoid arthritis. Ann Rhewm Dis 1976; 35: 138-42.

3 Delbarre F, Pompidou A, Kahan A, Broilhet H, Le Go A Amor B. Study of blood lymphocytes during systemic lupus erythematosus. Pathology and Biology 1971; 19: lupus eryth

4 Hunziker N, Brun R. Les basophiles dans le lupus erythemateux et certaines dermatoses. Dermatologica 1972; 145: 291-6.

5 Michael S R, Vural I L, Basser F A, Schafer L. The haematological aspects of disseminated (systemic) lupus erythematosus. Blood 1951; 6: 1059-72.

6 Isenberg D A, Martin P, Hajirousou V, Todd-Pokropek A, Goldstone A H, Snaith M L. Haematological reassessment of rheumatoid arthritis using an automated method. $\mathrm{Br} \mathcal{F}$ Rhevomatol 1986; 25: 152-7.

7 Isenberg D A, Patterson K G, Todd-Pokropek A, Snaith M L, Goldstone A H. Haematological aspects of systemic lupus erythematosus. A reappraisal using automated lupus erythematosus. A reappraisal using au

8 Arnett F C, Edworthy S M, Bloch D A, et al. The American Arnett F C, Edworthy S M, Bloch D A, et al. The American
Rheumatism Association 1987 revised criteria for the classification of theumatoid arthritis. Arthritis Rheum 1988; 31: $315-24$

9 Tan E M, Cohen A S, Fries J F, et al. The 1982 revised criteria for the classification of systemic lupus erythematosus. Arthritis Rhewm 1982; 25: 1271-7.

10 Bennet P H, Burch T A. Population studies of the rheromatic disease. Amsterdam: Excerpta Medica Foundation, 1968: 305.

11 Isenberg D A, Shoenfeld Y, Schwartz R S. Multiple serologic reactions and their relationship to clinical activity in
systemic lupus erythematosus. Of Med 1984; 27: 132-8.

12 Symmons D P M, Coppock. I S Med 1984; 27: 132-8. Development and assessment of a computerised index of clinical disease activity in systemic lupus erythematosus. $Q$ J Med 1988; 258 (New Series): 927-37.

13 Egido J, Sanchez Crespo M. Lahoz C, Garcia R, LopezTrascasa M, Hernando $\mathbf{L}$. Evidence of an immediate hypersensitivity mechanism in systemic lupus erythematosus. Ann Rhewm Dis 1980; 39: 312-7. 